\title{
Possibilities towards a socially just pedagogy: new tasks and challenges
}

\section{Ruksana Osman and David J Hornsby}

\begin{abstract}
$\underline{\text { Abstract }}$
This paper contributes to an emerging debate on what it means to transform teaching and learning in higher education and to renew the social justice mission of universities. By focusing on the teaching and learning environment, we set the stage for the special issue, exploring the idea of socially just pedagogy, where it comes from and what it means in the present day. The social justice-pedagogy nexus as taken up in this paper aims at using pedagogy as a change process to transform higher education. We offer new considerations arguing that to adopt socially just pedagogies it is important that teachers consider the personal dimensions of pedagogy, the politics of difference, and the relationship between pedagogy and agency. In doing this, the chance that universities remain places of possibility, rather than turning into divisive spaces, becomes more plausible.
\end{abstract}

\section{$\underline{\text { Introduction }}$}

More and more we see universities becoming microcosms of the divided and unforgiving world that we see globally. Instead of universities being the places of possibility and an example of what society can be, these are spaces that are contested on several fronts- alienating teaching culture, students laden with debt, closing down of spaces for debate and engagement and an overall approach to teaching and learning which is out of sync with the divided and deeply polarised worlds of students and their families. Ultimately, what we see unfolding is a 'crisis' of existence for the modern university in society- that is modern universities that remain resistant to change and transformation.

The global need for better higher education highlights the need to reposition ourselves as university teachers, particularly in relation to what we teach, how we teach and why we teach; this repositioning also provides universities with an opportunity to rethink education for social change; reforming university education to foster social awareness and societal betterment by preparing citizens who are able to take their place in a transforming society and world (Arvanitakis and Hornsby, 2016). Inspiring students to aspire for a world that is socially just, where socio economic and institutional arrangements would transform to reflect the changes in ideas, thinking, consciousness, and sensibilities and lived experiences. Such a moment presents creative and critical opportunities for imagining new ways to think about the university and its shared future globally, and to come up with organised and collective pedagogical responses from our own locations, affects and histories.

Through this paper and special issue we consider, do socially just pedagogies make a difference? Can they make a difference? What needs to happen for these to make a difference? For whom does it make a difference? Can these assist in restoring a less divided world? Is this a moment that recognises that some of societal solutions are indeed possible inside the university? Sylvia Wynter (McKittrick, 2014) reminds us of 
the importance of creative resistance as an important condition for making epistemic shifts and by implication pedagogic shifts in university teaching and learning. We agree that curriculum and pedagogy can be redesigned to assist university teachers and students in learning to see social justice, to critique epistemologies that privilege one way of knowing, and set aside unjust histories and values in search of values that reject exclusion and disrespect of other ways of knowing and being; this is important work for universities globally, more so in a world that is divided and underpinned by hate.

\section{Social Justice in Perspective}

Incorporating social justice ideas into teaching and learning requires that we develop pedagogical approaches that take into account student needs and encourage what Fraser (2003, 2009) calls "participatory parity."Liebowitz et al., (2017) argue that this idea requires pedagogical stances that treat all as equal in the classroom and ideally outside too. Fraser (2009:16) argues "[o]vercoming injustice means dismantling institutionalized obstacles that prevent some people from participating on a par with others, as full partners in social interaction." Ultimately this means that teaching and learning approaches in what and how we teach need to be tailored so as to overcome institutionalised exclusions if we are serious about transforming society. This means moving beyond what Liebowtiz (2009: 87) laments as an over emphasis on focusing "solely on the material, or on the affective and relational, or on the more directly academic and cognitive experiences" in our teaching and learning environments. Both Fraser (2009) and Liebowitz (2009) argue for a broader vision for teaching and learning that considers structural factors like the distribution of resources, fostering of participation, and recognition of identity, cultural affiliation or social status in our pedagogical practices.

Distribution in a teaching and learning context refers to ensuring that all have access to similar materials and resources in higher education. Participation speaks to ensuring our teaching and learning environments account for the fact that students come to the learning environments with contexualised understandings and pick up academic concepts and ideas through activities that resonate with their experiences of the world (Northedge 2003; Haggis 2006). This means that teachers need to permit space for learning that ensures participation as a key attribute of socially just pedagogies. Importantly, knowledge is situated given the contextual nature of knowing and of course constructed by the situated knower (teacher and learner/student) in a particular time and space.

Finally, recognition speaks to how we as teachers ensure students feel safe and welcome within an institutional teaching and learning space. Given that differences exists amongst the student body in social class, identity, and cultural affiliation it is important to recognise this and how it can affect a learning space. For example, Erasmus (2006) notes that racism can affect how black students learn - a lack of recognition of students background and experiences can make them withdraw from teaching and learning. Waghid (2009) argues that openness and dialogue are really important for achieving recognition and encourages teachers and students to develop a space to understand commonalities through teaching and learning. Soudien (2015: 156) points out that two priorities have to be met if we take transformation seriously, and these are social inclusion (diverse students and teachers) and epistemological hospitality (diverse 
knowledge). While it is clear that there is no one way of doing social justice or pedagogy, such work is about presenting pedagogical alternatives at the level of pedagogic ideas and pedagogical actions that fit most clearly within a frame of recognition and participation. But transformation in this context can also be seen as the redistribution of influence in learning and teaching in the university classroom, where the classroom is not only a microcosm of what society is but what it can be if we work with social justice substantively. In this sense it has the effect of shifting the university 'system from within itself' (Soudien, 2015: 154).

There are also normative ways which can be engaged with to challenge in order to achieve a socially just pedagogy. Maringe (2017) argues that we need to develop a moral and ethical purpose to our teaching practice, seek to delete cultural relativism and ethnoccentricism, liberate the learner from conformity, promote dialogical learning, and challenge learning cultures and spaces. Both Mupotsa (2017) and Kiguwa (2017) propose that to transform our learning spaces and effect social justice the assumptions of students need to be disturbed or disrupted through our pedagogical practices. Either way, structurally or normatively, with ideas driven by a social justice agenda, and effective teaching, a socially just university and society is possible, albeit a tall order.

Thinking through socially just pedagogies calls for a range of theorised understandings which can be called upon or recruited in deliberations on teaching and learning for social justice. It is through offering and exploring substantive theoretical and practical resources for the social justice project of teaching and learning that wider social change even becomes possible

Framed this way the university classroom becomes a powerful space for organised and collective social change. Transformation is at the level of ideas and consciousness and not just pedagogic action. Such a framing helps create a space for reasoning and dialogue and the deliberation of pedagogical alternatives to the current pressures for change and transformation.

To our mind this way of framing and responding to the current pressures on higher education is more suitable for transforming higher education and society more broadly than just pressure from authoritarian populism or policy directives. After all, universities too are living in conditions of neo liberal globalisation and they too remain central to the transformation project. The university classroom seems to be the ideal place and space for enacting and imagining new futures and opening up possibilities of mutuality.

\section{Socially Just Pedagogy: the Concept}

The notion of socially just pedagogies can be linked historically to the ideas of critical pedagogy and critical agency. Drawing upon and critiquing early Marxism, the idea of critical pedagogy is based on the understanding that education in capitalist societies tends to reproduce relations of inequality and acts as ideological mechanisms of the state. Critical pedagogy then raises awareness about the workings of capitalism and foregrounds the importance of an education for emancipation (Freire, 2005), as opposed to an education for domination (Nkomo, 1990) and indoctrination. Freire (2005) noted 
that education in capitalist society, which are based on "banking methods" of teaching and learning do not promote critical thinking. It is critical pedagogies which are based on critical thinking and democratic participation that enable possible transformations and change of capitalist societies. In this regard, then, transformative pedagogies are about being critical, thinking critically, enabling democratic educational relations and empowering people to be critical agents in order to transform unequal capitalist orders.

Socially just pedagogies link up currently with notions of liberal pedagogies (Young, 2000), emancipatory pedagogies (Torress and Morrow, 1995), and border pedagogies (Giroux, 1988). Such notions of pedagogies attempt to engage with what critical pedagogy could mean in advanced capitalist, postmodern and postcolonial conditions. These types of pedagogies all assume the importance of critical thinking as the basis for enabling critical agency for transformation. As such, they presuppose several things: from relations between structures and agents; what constitutes alternatives in transformative terms; to individual and collective forms of action. In many ways as well, these presuppositions are being called to question because they point to shifts from colonial to postcolonial situations (see Mbembe, 2001) and from modern to postmodern conditions (see Hall et al, 1992), locally and globally, and the kind of social actions they enable. Socially just pedagogies are about developing and fostering critical thinking to enable people in such conditions to exercise critical agency in order to transform contemporary orders on the basis of social justice. It is about being propelled by a passion to create a just society - "one that ...links struggle to a new set of human possibilities" (Giroux, 1983: 242). Said famously reminds us that critique and 'dedicated consciousness' are essential in fighting for our rights and our future.

\section{The Pedagogic is Personal}

The vision for socially just pedagogies is to foster individuals interested and capable of nurturing social change. This brings to the fore a variety of complex issues which relate to the individual nature of knowing, learning and teaching on the one hand, and the personal and affective dimensions of knowing, learning and teaching on the other. Such pedagogies disrupt the familiar divisions between teacher and student and require learning spaces to consider multiple ways of knowing emanating from countless sites of practice - with the personal and the emotional ever present. Given this complexity the danger always exists that socially just pedagogies can become an empty label or the link to a just social vision is automatic.

It may also appear that socially just pedagogy lacks academic and disciplinary integrity as it too easily slips into the subjective and the affective. We propose that doing social justice work engenders moments of self-doubt for teachers and students about epistemology and pedagogy, which are crucial to transforming how teaching and learning takes place in higher education, right across the world.

On another level, these complexities around the personal and the affective raise questions about the nature of higher education institutions as spaces for social justice. They point to the structural limitations of universities. For example, how does the institutional culture impact on the capacity of such institutions to be responsive? What acts of resistance are required of staff to facilitate equity and redress through education? What are the costs to staff as they come in direct conflict with normative values, beliefs and assumptions prevalent in higher education institutions? While this paper addresses 
some of these questions, the various papers in the special issue take these up to varying degrees.

In spite of the complexities discussed above, an important aspect of socially just pedagogy is for university teachers to place their practices, interpretations and biases before others for scrutiny. It could mean being open to present ones pedagogical practices for wider examinations by colleagues working in similar contexts. This kind of scholarly approach to social justice work falls well within the scholarship of teaching and learning paradigm (SoTL). SoTL provides an opportunity to re-examine, and in some instances confirm ones epistemological and philosophical orientation as teachers as well as recognise the political nature of our work (see Liebowtiz et al., 2017). Or it could also be related to ensuring student voices are heard and strengthened through our pedagogical practices.

\section{The Politics of Difference}

Socially just pedagogies also highlights that “... each of us, though unique as individuals, is positioned within society, along hierarchies of power constructed around ... class, caste, race, gender, age and sexuality" (Brah and Hoy, 1989: 71). Philosophically and pedagogically a social justice approach acknowledges the material positions of teachers and students in terms of race, class and gender and even location. It foregrounds the politics of difference and knowledge, power and inequality are firmly on the agenda. It pushes the boundaries so that the academy and the university classroom is the place for asking what why, why not and where among other questions.

Such approaches while daunting for teachers and students, create opportunities and space to talk about and propose curricula that are open and empowering to the world in which students' knowledge is constructed. In this moment possibilities of mutuality are made and acted upon. Teaching and assessment practices are selected for their capacity to take into account knowledges that are usually invisible in the institution, thereby enriching the knowledge project. Various methods are used and could include focus group discussions, talking and listening, argument and speculation, research seminars, community projects, re-enactments, collages, dialogue, narrative, life histories and other forms of self-expression such as music and dance. Whatever the pedagogic stance selected, sharing and reciprocity and mutual constitution are the underpinnings rather than domination and authority. In addition, students themselves are empowered to engage with the contested nature of knowledge. Such approaches and process weave the private and public lives of teachers and students into integrated and whole realities and call into question dichotomies that are ever-present in our classrooms.

\section{Pedagogy and Agency}

The theme of agency as central to socially just pedagogies and social change cannot be overstated. Agency speaks to recognising the power individuals and inherently about ways of empowering those whose voice may typically be excluded. Pedagogical stances that enhance agency naturally counter oppressive systems and actions fostering societal transformation. For example, pedagogical approaches that relate the idea of social change to ideas that nothing is fixed, that change can be achieved if individual and collective agency is appreciated and activated, can be transformative (Carrim, 2017). Further, a pedagogy that seeks to affirm can be transformative as it can build confidence in students helping them to realize or unlock their capabilities (Mupotsa 2017; and Liebowitz et al., 2017). Pedagogical strategies that challenge students to confront their own prejudices around issues of race can also enhance agency as they 
build awareness of how they limit the space for others (Maringe 2017; Iqani and Falkof, 2017; and Kiguwa, 2017). Finally, agency as inherent in pedagogy work towards national projects to reconcile difficult pasts or assert rights of particular groups within communities (Kurup and Singai 2017; Bagelman and Tremblay, 2017; and Wintjes, 2017). Social change and the centrality of human agency in such change epitomise transformative pedagogies. Of course some will question the capacity for socially just pedagogies to challenge hegemonic discourses that permeate the university. It is our contention that in spaces where there is a history of flexibility around curriculum change and in contexts where there is pressure for change socially just pedagogies stand a good chance.

\section{The Work of Socially Just Pedagogies}

Engaging in socially just pedagogies often places the teacher in difficult and uncomfortable positions and thus is not easy to undertake. It as much challenges those responsible for constructing a learning environment as it does for those engaging and participating in it. As such, it is also important to think through how best to support colleagues and institutions to adopt socially just pedagogies. Indeed, what are the conditions required for them to thrive? What are the institutional conditions that facilitate or constrain the creation of 'just' classrooms?

A condition that we consider paramount is the idea of the classroom as a dialogical space where teachers and students alike can explore and build understanding around the issue at hand without silencing particular voices. In effect, we need to reinvigorate the traditional social compact in university spaces where academic freedom, freedom of expression, and openness to difference are valued and encouraged and where authoritarian populism is challenged.

Another condition apparent is a commitment for individual institutions to place resources into support for curriculum reform and staff development in line with the integration of social justice practices. Resources can range from moral and financial support, to the establishment of considered and protected spaces to discuss and think through how transformative pedagogies could take shape and be most effective. To reframe our learning spaces to focus on the notion of social justice requires a degree of encouragement from institutional structures, so as to overcome those who are resistant to change. Here SoTL can be a helpful mechanism to build space, understanding, and institutional support in this respect (Osman and Hornsby, 2016; Liebowitz et al., 2017). SoTL is an effective way to experiment with socially just pedagogies as it enables one to step back and take a larger 'balcony view' of the impact and context that needs to be addressed. Essed (1991) reminds us that a balcony view allows one to experiment outside the fray of university politics and the structural limitations of universities.

\section{The Global Moment For Change and Transformation}

We argue that what and the way we teach matters significantly to the social justice mission inherent in higher education. We have constructed a set of arguments in this paper that seek to clearly link social justice and transformation with pedagogy. We also made reference to some of the complexities associated with such pedagogy. Whilst our location and experience is primarily guided by the South African experience, we noted that social justice, transformative pedagogies, and higher education are linked no matter one's location and history. We pointed out that the South African moment is linked to a global moment for change and transformation. If you consider that transformative pedagogies for social justice is about challenging and changing taken-for-granted 
approaches to knowledge, teaching, learning and assessing then the ideas presented in this paper and in the special issue have purchase in any higher education environment in the world. These are the ideas that keep the human spirit alive to new possibilities and new futures.

The current climate in higher education globally provides a rich opportunity for theorising education for social justice. Thinking of socially just pedagogies is an innovation in higher education that requires a variety of shifts. First, an institutional culture that is open and responsive to exploring the different ways of seeing and being and where pedagogy and social innovation meet, is required. Such an exploration will put pressure on existing curricula within institutions as they challenge the nature of knowledge making and the knowledge project of the university. This leads to a second required shift: an academic cohort committed to acts of resistance in the service of social justice through transformative pedagogies. The transformative potential of higher education is clear and we acknowledge that this may not be immediately apparent to all, particularly those who believe higher education is about the transfer of disciplinary content and credentialing rather than expanding understandings and questioning knowledge and knowledge traditions. This means that without explicit buyin and acceptance from colleagues, implementing transformative pedagogies as a rule, rather than exception is difficult and requires concerted emphasis and focus. From our perspective, this is necessary and important in ensuring higher education stays relevant to societal needs and demands going forward.

\section{References}

BBC. (2016). Chile student demonstration turns violent in Santiago. BBC News. 27 May. Accessed from http://www.bbc.com/news/world-latin-america-36394771

Bagelman, C., and Tremblay, C. (2017). Where Pedagogy and Social Innovation Meet: Assessing the Impact of Experiential Education in the Third Sector. In Ruksana Osman and David J Hornsby (eds) Transforming Teaching and Learning in Higher Education: Towards a Socially Just Pedagogy in a Global Context. Palgrave MacMillan: London. 191-218.

Brah, A., and Hoy, J. (1989). Experiental Learning: A New Orthodoxy?, in Weil and McGill (eds) Making Sense of Experiential Learning: Diversity in Theory and Practice, Buckingham: Open University. pp.70-77.

Burke, J. (2016). Protests to continue at Indian University after student leader's arrest, The Guardian, Monday February 15. Accessed from https://www.theguardian.com/world/2016/feb/15/jawaharlal-nehru-universitykanhaiya-kumar-student-arrest-india

Carrim, N. (2017). Stuart Hall and Education: Being Critical of Critical Pedagogy. In Ruksana Osman and David J Hornsby (eds) Transforming Teaching and Learning in Higher Education: Towards a Socially Just Pedagogy in a Global Context. Palgrave MacMillan: London. 15-36. 
Erasmus, Z. (2006). Living the future now: 'Race' and the challenges of transformation in higher education. South African Journal of Higher Education, 20(3): 413-425

Essed, P. (1991). Understanding Everyday Racism: An Interdisciplinary Theory. Thousand Oaks, CA, US: Sage Publications.

Flood, A. (2016). Yale English students call for end of focus on white male writers. The Guardian. 1 June. Accessed from https://www.theguardian.com/books/2016/jun/01/yale-english-students-call-for-endof-focus-on-white-male-writers

Fraser, N. (2009). Scales of Justice: Reimagining political space in a globalising world. New York: Columbia University Press.

Freire, P. (2005). Pedagogy of the Oppressed: $30^{\text {th }}$ Anniversary Edition. New York: The Continuum Publishing Group Inc.

Giroux, H. (1988). Border Pedagogy in the Age of Postmodernism Journal of Education (Boston University) 170 (3) pp. 162 - 181.

Giroux, H.A. (1983). Theory and Resistance in Education: A Pedagogy for the Opposition. Bergin \& Garvey.

Gramsci, A., 1971. Selections from the Prison Notebooks. International Publishers Isin and Nieslen 2008.

The Guardian. (2016). Black Lives Matter movement. August. Accessed from https://www.theguardian.com/us-news/black-lives-matter-movement

Haggis, T. (2006). Pedagogies for diversity: Retaining critical challenge amidst fears of 'dumbing down'. Studies in Higher Education, 5(31): 521-535.

Hall, S; Held, D; and, McGrew, T. (1992). Modernity and its Futures Cambridge: Polity Press.

Iqani, M., and Falkof, N. (2017). Race, Gender and "Personal" Pedagogy: Emotional Encounters in the Post-Apartheid Classroom. In Ruksana Osman and David J Hornsby (eds) Transforming Teaching and Learning in Higher Education: Towards a Socially Just Pedagogy in a Global Context. Palgrave MacMillan: London. 155-174.

Kiguwa, P. (2017). How and Why do We Disturb? Challenges and Possibilities of Pedagogy of Hope in Socially Just Pedagogies. In Ruksana Osman and David J Hornsby (eds) Transforming Teaching and Learning in Higher Education: Towards a Socially Just Pedagogy in a Global Context. Palgrave MacMillan: London. 99-118.

Kurup, A., and Singai, C. (2017). Redefining University Education in India: Pedagogy and Student Voices. In Ruksana Osman and David J Hornsby (eds) Transforming Teaching and Learning in Higher Education: Towards a Socially Just Pedagogy in a Global Context. Palgrave MacMillan: London. 175-190.

Liebowtiz, B. (2009). Towards a Pedagogy of Possibility: teaching and learning from a 'social justice' perspective. In Eli Blitzer (ed) Higher Education in South Africa: a scholarly look behind the scenes. Stellenbosch: SUN Press. 85-102. 
Liebowitz, B., Naidoo, K., and Mayet, R. (2017). Teaching in and for Social Justice. In Ruksana Osman and David J Hornsby (eds) Transforming Teaching and Learning in Higher Education: Towards a Socially Just Pedagogy in a Global Context. Palgrave MacMillan: London. 79-98.

Maringe, F. (2017). Creating Opportunities for a Socially Just Pedagogy: The Imperatives of Transformation in Post-Colonial HE Spaces. In Ruksana Osman and David J Hornsby (eds) Transforming Teaching and Learning in Higher Education: Towards a Socially Just Pedagogy in a Global Context. Palgrave MacMillan: London. 59-78.

Mbembe, A. (2001).On the Postcolony. Berkeley and LA: University of California Press.

McKittrick, K, (2014). Sylvia Wynter: on being human as praxis. Raliegh, North Carolina: Duke University Press.

Mupotsa, D. (2017). Being/Becoming an Undutiful Daughter: Thinking as a Practice of Freedom. In Ruksana Osman and David J Hornsby (eds) Transforming Teaching and Learning in Higher Education: Towards a Socially Just Pedagogy in a Global Context. Palgrave MacMillan: London. 37-58.

Nkomo, M, (1990). Pedagogy for Domination. Trenton: Africa World Press.

Northedge, A. (2003). Rethinking Teaching in the Context of Diversity. Teaching in Higher Education, 8(1): 17-32.

Osman, R., and Hornsby D.J.. (2016). Communities and Scholarship in supporting Early Career Academics at the University of the Witwatersrand. Studies in Higher Education.

Rhoden-Paul, A. (2016). Oxford Uni must decolonise its campus and curriculum, say students. The Guardian. 18 June. Accessed from https://www.theguardian.com/education/2015/jun/18/oxford-uni-must-decolonise-itscampus-and-curriculum-say-students

Soudien, C. (2015). Interrogating Transformation in South African Higher Education. In Xolela Mangcu (ed). The Colour of Our Future: Does Race Matter in Post-Apartheid South Africa? Wits University Press.

Torres, C A \& Morrow, A. R. (1995). Social Theory and Education: A Critique of Social and Cultural Reproduction, Albany: State University of New York Press.

Waghid, Y. (2009). Universities and public goods: In defence of democratic deliberation, compassionate imagining and cosmopolitan justice. In Eli Blitzer (ed) Higher Education in South Africa: a scholarly look behind the scenes. Stellenbosch: SUN Press. 71-84

Weick, K.E. (1984). Small Wins: redefining the scale of social problems. American Psychologist, 39(1): 40-49.

Wintjes, J. (2017). Thinking Through Things: The Transformative Work of the Object Biographies Project. In Ruksana Osman and David J Hornsby (eds) Transforming 
Teaching and Learning in Higher Education: Towards a Socially Just Pedagogy in a Global Context. Palgrave MacMillan: London. 137-154.

Young, I. M. (2000). Inclusion and Democracy (Oxford, Oxford University Press). 